\title{
NOTES ON THE CHANGA, OR WEST INDIAN MOLE CRICKET, IN PUERTO RICO IN 1935 AND 1936
}

By A. H. MADDEN, Junior Entomologist, Division of Truck Crop and Garden Insect Investigations, Bureau of Entomology and Plant Quarantine, United States Department of Agriculture

\section{INTRODUCTION}

A study of the changa (Scapteriscus vicinus Scudd.) was conducted in Puerto Rico in 1935 and 1936 by the Bureau of Entomology and Plant Quarantine, United States Department of Agriculture, in cooperation with the Puerto Rico Agricultural Experiment Station at Mayagüez. During this period changa damage was apparently not so severe as it has been in the past, according to the observations of previous workers. This was perhaps partly due to the severe drought which extended over practically the entire Island during part of this period, for although this drought occurred during the normal dry season it exceeded in severity those of all previous Weather Bureau records covering a period of 25 years. Under such conditions changa damage is normally much less severe.

Sugarcane comprises approximately 35 percent of the entire marketable crops produced on the Island and a much larger proportion: of the crops susceptible to changa damage. Although repeated observations were made in the sugarcane fields over the entire Island, however, in only a few instances was any appreciable changa damage noted. Damage to coffee, the second largest crop, was limited to a few slight infestations occurring in seedling beds. Tobacco, ranking third as an economic crop, is considered one of the favorite host plants of the changa, but there was no important damage to this crop, and the heaviest infestation was that observed in a small field of approximately three-fourths of an acre in which 10 percent of the plants had been destroyed. The only cases of severe damage were confined to minor crops such as sweet corn and vegetables, several cases having been observed in which from 50 to 98 percent of the crop was destroyed. In practically all of these cases, however, the planting did not exceed 1 acre and the resulting commercial loss was therefore relatively slight.

A part of the popular belief existing on the Island concerning the seriousness of the changa problem is doubtless due to the fact 
that a considerable amount of damage caused by other insects is attributed to the changa. Damage by white grubs and cutworms is often confused with changa damage, and cases have come to the writer's attention in which chinch bugs, millipedes, and even fungus diseases, were causing the reputed changa injury.

\section{Distribution}

Distribution limited to definite areas of the Island.-One of the main purposes of this project was to determine the limits of distribution of the changa on the Island. This was accomplished by making extensive surveys over practically the entire area. This insect was found to occur in the following localities: Aguirre, Añasco, Arecibo, Arroyo, Bejuco, Cabo Rojo, Caguas, Carolina, Cayey, Corozal, Florida, Guayama, Hormigueros, Humacao, Isabela, Lajas, Las Marías, Loíza, Maleza Baja, Maricao, Mayagüez, Pueblo Viejo, Río Piedras, Quebradillas, and Yabucoa. Since practically all of these points are around the coast or within the interior river valleys, the observations indicate that the distribution of this insect is limited to such areas. Other workers on the changa in Puerto Rico have reached similar conclusions.

Type of soil the chief factor limiting distribution.- Such factors as elevation, temperature, and distribution of host plants appear to have little or no effect on distribution. Abundance of rainfall seems to be of some importance, there being apparently more changas in the areas receiving the greatest amounts of precipitation. The chief factor limiting distribution is undoubtedly the type of soil. Distribution is quite definitely limited to light-textured, sandy soils. These soils are particularly adapted to the burrowng activities of the changa and thus afford the most suitable environment. In heavy clay soils, the insect is either very rare or entirely absent. Unfortunately, soils best suited to the growing of vegetables and similar crops are the only soils inhabited to any great extent by the changa; consequently damage to such crops is particularly heavy unless control measures are employed.

\section{Host Plants}

The changa feeds upon a wide range of host plants. Feeding has been observed by the writer on the following: Basil (Ocimum basilicum), bean, cabbage, coffee seedlings, young cotton plants, cucumber, eggplant, sweetpotato, tobaceo, and various grasses. Only plants showing visible evidence of feeding on the stem at the crown were 
included in this list. Severe injury is caused in this manner and usually results in the destruction of the plant. Other workers on the Island report the changa as feeding upon the following, in addition to the plants in the foregoing list: Cantaloup, collard, onion, pea, rape, rice, turnip, Colsus spp., and Livingstowia spp. In fact, almost any young plant may serve as food, although plants having a poisonous or acrid sap are said to be avoided.

The writer's cage studies and field observations have shown that the changa feeds also to a considerable extent on decomposing organic matter in the soil, and it has been found that it feeds upon its own and other species of insects.

\section{DAMAGE}

Damage to plants by the changa results mainly from its feeding activities, but some damage results from the uprooting of the seedling plants caused by movements of the changa through the soil. Feeding is confined entirely to the roots and stems, usually at the crown in the latter case. Stems are either completely severed or are so badly gnawed that they are no longer able to support the weight of the plant. Obviously, the greatest amount of damage results from this type of feeding, since injury to the stem usually causes the loss of the entire plant.

The greatest damage normally occurs after heavy rains or after the soil has been moistened by irrigation. This is because the changa is active at the surface only when the soil is sufficiently softened by moisture to permit such activity, and it is at such times that feeding upon stems occurs. Since feeding on the roots of plants produces little appreciable damage, it is apparent that the most injury can take place only under the above conditions. In general, the greatest amount of damage may be expected during the rainy season.

\section{Natural Enemes of the Changa}

A number of native birds are known to be of value in preying upon the changa. These have been recorded by Wetmore (U. S. Dept. Agr. Bul. 326, 1916). The more important of these are listed here in the order of their importance:

Martinete, or green Cuban heron Falcón, or Puerto Rico sparrow hawk

Playero, or Antillean killdeer Putilla, or spotted sandpiper

(Butorides virescens maeulatus)

(Falco sparverius loquaculus)

(Oxyechus vociferus muidus) (Actitis macularia) 
Garza, or little blue heron

Judio, or smooth-billed ani Ruiseñor, or Jamaican mockingbird

Clérigo, or Puerto Rico petchary Pitirre, or gray kingbird

Juí, or Antillean flycatcher Garzón blanco, or American egret (Casmerodius albus)

(Florida caerulea)

(Crotophaga ani)

(Mimus polyglottos orpheus)

(Tolmarchus taylori)

(Tyrannus dominicensis dominicensis)

(Myiarchus antillarum)

These birds should receive every possible protection.

A few minor enemies, such as ants, spiders, and lizards, have been recorded, but these are relatively unimportant.

Observations have been made which indicate that the giant toad (Bufo marinus) is an important enemy of the changa. This animal was first introduced into the Island in 1920 and it appears to have been playing a considerable part in the control of the changa since that time. An examination of the stomachs of a small number of these toads during the latter part of 1935 revealed that the changa comprised about 15 percent of the stomach contents. This, however, is probably not a true indication of the extent to which they are preyed upon by the toad, because, owing to the dry condition of the soil, changas were not very plentiful at the time.

\section{Good Control by Poisonen Baits}

Satisfactory control of the changa can be obtained by the use of poisoned baits. The bait formulated by Crossman and Wolcott in 1915 is extensively used on the Island and is fairly efficient. It consists of a mixture of paris green and flour, the proportion of paris green being from 3 to 10 percent of the total mixture. Three percent of paris green is usually sufficient.

The bait should be broadcast over the field at the rate of 300 pounds per acre about one week before planting. This should be done as late in the afternoon as possible, preferably after a rain, since the best results are obtained when the surface of the soil is wet. In cases of severe infestation a second application may be necessary, and this also should be made prior to planting, since it is very difficult to apply this bait broadcast in a field containing growing plants and avoid burning them. The bait may also be applied around individual plants. In this case, shallow trenches are first made around each plant and a small quantity of bait is placed around the bottom of each trench. Applications of this type require only about 
150 pounds of bait per acre, but all other conditions mentioned above should be observed.

Some work was completed which indicated that the substitution of wheat bran for flour increased the efficiency of the bait. This should first be mixed thoroughly with the paris green and then the mixture should be moistened with water until a handful of the mixture will no longer fall apart or break up after being compressed, but not enough water should be added so that any moisture can be extracted in this way. Applications can be made in the same manner as described above.

\section{Other Methods of Chemical Control of Some Value}

It was found that a mixture of 8 ounces of pyrethrum powder to 2 gallons of water, when poured over the surface of the soil, kills the changas immediately below the surface. This method of control should be used only when the soil is wet; and since the cost of the material is high, its use is restricted to special cases where the cost is justifiable.

A strong solution of blue soap (the common laundry soap obtainable anywhere on the Island) and water when used as above is of considerable effectiveness. This mixture should be poured into individual burrows if possible. It should be applied at an early hour in the morning when the changas are near the surface in the fresh burrows made the preceding night. All changes driven to the surface may be readily collected and killed. With this treatment killing is necessary since the action of the soap and water renders the mole crickets inactive for only a short time. 


\section{Summary}

Distribution of the changa is limited to the coast and to the interior river valleys of the Island. Type of soil is the chief factor limiting distribution.

A wide variety of host plants are attacked, but a slight preference appears to be shown for certain plants.

The main damage results from feeding, which is confined to the roots and stems of plants. The greatest damage occurs when the surface of the soil is wet.

Few, if any, important natural enemies of the changa, other than birds, are native to the island, although the introduced giant toad seems to be proving a valuable aid in control.

Poisoned baits afford a satisfactory means of control, and other means of chemical control may be employed. 